\title{
What Makes Firms Perform Well? Evidence from Ghana Retail Shops
}

\author{
Ebenezer Appiah $^{1 *}$, Koudalo Yawovi Mawulikplim Agbekoํ, Toure Moumbark1, Rahman Dunya ${ }^{2}$ \\ ${ }^{1}$ Research Institute of Economics and Management, Southwestern University of Finance and Economics, Chengdu, China \\ ${ }^{2}$ College of Management, Sichuan Agricultural University, Chengdu, China \\ Email: ^ebenezerkojoappiah@gmail.com, koudgodwin@yahoo.com, touremoubarak10@yahoo.com, rascom98@ymail.com
}

How to cite this paper: Appiah, E., Agbeko, K.Y.M., Moumbark, T. and Dunya, R. (2020) What Makes Firms Perform Well? Evidence from Ghana Retail Shops Theoretical Economics Letters, 10, 250-271. https://doi.org/10.4236/tel.2020.101016

Received: November 8, 2019

Accepted: February 25, 2020

Published: February 28, 2020

Copyright $\odot 2020$ by author(s) and Scientific Research Publishing Inc. This work is licensed under the Creative Commons Attribution International License (CC BY 4.0).

http://creativecommons.org/licenses/by/4.0/

\begin{abstract}
Small and Medium Enterprises are an integral part of the modern world. In today's intensively competitive business environment, the retail industry will be more important for developing economies because of the rising unemployment rate. The growth of the retail shops, however, is hindered to a large extent of challenges. Observing the growth of the retail industry in Ghana recently, one can conclude that the sector is significantly developing with numerous challenges surrounding it. Hence the question, what makes small firms perform well needs to be addressed properly, particularly in the case of retail shops in Ghana. The data used in this study was collected by distributing questionnaires to retail shop owners. 348 out of 423 questionnaires were answered and returned successfully. The study then employed OLS, logit, and probit regression models to analyze the impact of numerous factors that influence the growth of retail shops. The study revealed that factors such as training, access to market, business experience of retail shops owners, and access to transportation are positively associated with the growth of retail shops whereas factors like gender, age, education, start-up capital, access to credit, and social network are negatively associated with the growth of retail shops. Based on the findings, this study recommends that the government of Ghana should pay much attention to the sector by providing training to retail shop owners and their employees in order to have access to the necessary entrepreneurship training that will equip them to manage the affairs of their business which will at long-run influence economic growth.
\end{abstract}

\section{Keywords}

Small and Medium Enterprise, Retail Shop, Firm Growth, Ghana

\section{Introduction}

Small and Medium Enterprises are integral part of the modern world. The do- 
mination of Small and Medium Enterprises in both developed and developing countries cannot be underestimated. Due to the increasing operation of the sector, it has attracted scholars' attention and has been admitted to be the lifeblood of most economies. In Ghana, it is estimated that retail shops account for $70 \%$ of Ghana' Gross Domestic Product (GDP) and 92\% of its businesses (2010 population census). However, retail shops not only contribute significantly to the economy but also serve as the means of efficiently allocating resources to every sector of the nation. In Ghana, for instance, the retail sector employs the largest number of workers and constitutes about $90 \%$ of all registered businesses in the country (Adade \& Ahiawodzi, [1]). Formalized retail shops also contribute an estimated $49 \%$ of the Gross Domestic Product and this target group has been identified as the catalyst for economic growth of the country (2010 population census).

In today's intensively competitive business environment, the retail industry will be more important for developing economies because of the population increase. Retailing entails the business activities involved in selling goods and services to consumers for their personal, family, or household use. A retailer is one who stocks the producer's goods and is involved in the act of selling it to the individual consumer, at a margin of profit. Retailing is the last stage in a distribution channel, which contains the businesses and people involved in physically moving and transferring ownership of goods and services from producer to consumer (Berman \& Evans, [2]).

The retailing landscape has changed significantly during the last two decades. The retailing industry in the world has converted from the domestic market-based traditional market format of the past to large-scaled franchising and establishment of brand names (Kim et al., [3]). Income, technology and lifestyles of consumers are changing, even from whom they buy are changing. The location or the place where they buy is changing; the shops are opened closed according to the convenience of the buyers. The purchasing function has gained great importance and the desires; expectations and preferences of consumers have been changing rapidly in the competitive markets due to factors such as globalization and technological change recently. Changes in technology bring new attitude to buying products and services and to better organization of the supply chain (Londhe, [4]). According to Liu et al. [5] in their quest to investigate contract designing for a supply chain with uncertain information based on confidence level, they disclosed that when a supplier has a high variable cost and a low fixed cost, another has a low variable cost and a high fixed cost, and their variable costs are uncertain, assuming they sell the same product to a retailer based on respective contract menu, the retailer will be compelled to choose the contract menu that maximizes her alternative profit based on her confidence level instead of her expected profit. Chen et al. [6] on the other hand analyze the pricing and effort decisions of a supply chain with single manufacturer and single retailer. They are of the view that, a retailer can influence demand through sales effort. They discovered that the producer benefits from enrichment in de- 
mand and cost uncertainties when he has at least bargaining power in the supply chain.

Implying that with current rapid growth in technology, businesses need to pump in more capital to enhance their profitability. It is the goal of every business to expand and grow in terms of every aspect of their businesses. Of late, more studies have concluded that growth is a very complex and multifaceted process (Baum et al. [7]). It is implicit in many studies that growth is ideal (Masurel \& Van Montfort, [8]). Statistics show that worldwide, an extremely low percentage of entrepreneurs expect to grow their business substantially within five years (Autio, [9]). According to Mr. Luri, Ghana's retail sector has come a long way from the previous dominance of the informal retail sector where shoppers only choice were to go down to the local markets for all their shopping needs. Now, various shops are springing up in neighborhoods where one could purchase convenient items. As the growth continues, larger supermarkets that provide parking, air-conditioned shopping spaces and a wider variety of goods are becoming more prevalent.

Retailers are finding it increasingly difficult to survive and thrive in today's cut-throat competitive environment. Retail firms have also grown at an exceptional speed and are today largely composed of huge international corporations. At the same time, consumers have become more mobile, creating demand for specialized goods and services from retail clusters in locations easily accessed by car. There is growing preference by affluent and upper middle classes for shopping at modern organized retail shops, given the convenience they offer such as shopping ambiance, variety and a single point source of purchases. There is no doubt that traditional retail has been performing a vital function in the economy and significant source of employment.

Growth however, is hindered to a large extent by challenges, looking at the growth of the retail industry in Ghana, one can conclude that it is significantly increasing in recent times but it is also coupled with numerous challenges. Challenges such as expensive rent of facilities, increase in Value Added Tax (VAT) on goods and services, clearing challenges at the port, high import charges, high inflation, power crises and others. Growth of retail shop can also be measured quantitatively like units of sales/percentage of market share and quantity of stock held. In several research works the term "firm growth" and "firm success" have used interchangeably.

Growth means the comparison of the value created by a firm with the value expected by the starter. The on-hand literatures on firm growth have been extended into two main streams. The first line of study concentrates on the study of ways to enhance the firm's growth and the second deals with the study of different influencing factors on the growth of the business (Herath \& Mahmood, [10]). Several studies have revealed variations in growth when they used it as a dependent variable in the context of SMEs. Majority of the studies used profitability as a key dimension of firm growth in the context of entrepreneurship (Stuart \& Abetti, [11]; Begley \& Boyd, [12]). To measure firm performance, 
mostly profitability and growth rate of employment is used. According to Chandler and Jansen [13], the firm should not combine the two measures to generate a single measure for business growth. The predictor firm's growth studied in this paper is based on the firm's employment. The difference in terms of employment will tell whether the retailer is experiencing growth or not.

A competitive market is a market in which a large number of retailers compete with each other to satisfy the wants and needs of a large number of consumers. In the market there is free entry and free exit, low entrance cost, huge number of firms and homogenous products which makes market dominance more difficult for a retail shop owner because every owner of a business in the market is a price taker. This makes no single retailer, or group of retailers and no single consumer, or group of consumers, able to dictate how the market operates. In the competitive market because all consumers and retailers are informed about the market it is very difficult for one retail shop owner to increase his or her price abnormally because there is a substitute. The distance of one retail shops is very close to each other to the extent that some of the shops are been separated by wall of a building which tells the competitive nature of the market. Due to the competitive nature of the market some retail shop owners find it very difficult to penetrate the market especially the new members with the exception of the smart once who are able to use innovate way to find his way through because the same goods are sold different retailers in the same market. One reason for the importance of studying the factors influencing the growth of retail shops is the economic size of this sector and, consequently, the substantial amount of resources devoted to it in any developing economy.

There is a diminutive agreement in the present literature on the measurement of growth. Thus, majority of the previous researchers measure growth in diverse ways including total assets, profit and sales among others (Davidsson \& Wiklund, [14]). It is difficult to access accurate data on fixed assets and sales of SMEs or retailers especially due to poor record keeping making their fixed/sales or profit unfit indicator to measure growth in our study. We therefore used initial employment and current employment of the retailers based on each model. For instance, growth was measured as the differences between the initial employment and current employment for the ordinary least square (OLS), we then grouped the differences into two categories thus positive numbers of $1-10$ and coded as 1 representing growing retail shops whereas 0 to -10 coded as 0 represent non-growing shops for the binary logit model and probit model. Despite this increased competitive intensity, few studies have identified the factors that influence the retail growth in the country using this approach. This paper contributes significantly by showcasing a different approach of measuring growth of retail shops.

\section{Model Specification, Data and Estimation Techniques}

In order to explore the main research objective, the study used ordinary least 
square, logit and probit regressions to examine the factors influencing the growth of Small and Medium Enterprises in Ghana. Refer to Model 1, 2 and 3 below.

\section{Model 1:}

The ordinary least square regression for estimating the impact of factors that influence growth of retail shops assumes the following specification:

$$
\begin{aligned}
D N E= & \alpha+\beta_{1} G E N+\beta_{2} A G E+\beta_{3} E D U+\beta_{4} B E \\
& +\beta_{5} T+\beta_{6} R L+\beta_{7} S U C+\beta_{8} A T+\beta_{9} A M \\
& +\beta_{10} A C+\beta_{11} A P S+\beta_{12} S N+\varepsilon
\end{aligned}
$$

\section{Model 2: Logit regression}

In order to analyze the main research objective, the study will use a logistic regression to examine the factors influencing the growth of microenterprises in Ghana. The study followed Baum et al. [7], and Alemayehu and Gecho [15] to use the growth in employment as a measure of microenterprise growth. In this vein, microenterprises are grouped as either growth or non-growth based on whether the enterprise is experiencing employment growth or otherwise. The empirical logit regression model for this study can be expressed in the following form:

$$
\begin{aligned}
\operatorname{Logit}\left(Y_{i}\right)= & \alpha+\beta_{1} G E N_{i}+\beta_{2} A G E_{i}+\beta_{3} E D U_{i}+\beta_{4} B E_{i} \\
& +\beta_{5} T_{i}+\beta_{6} R L_{i}+\beta_{7} S C_{i}+\beta_{8} A T_{i}+\beta_{9} A M_{i} \\
& +\beta_{10} A C_{i}+\beta_{11} A P S_{i}+\beta_{12} S N_{i}+\varepsilon_{i}
\end{aligned}
$$

\section{Model 3: Binary Probit model}

The probit model was also developed to analyze regression framework which have a dichotomous dependent variable. According to Nagler [16], probit model constrains the estimated probabilities to be between 0 and 1 and relaxes the constraint that the effect of the independent variable is constant across different predicted values of the dependent variable. The study also utilizes the probit model because of the normality assumption of the probit model, given that several specification problems are more easily analyzed because of the properties of the normal distribution (Wooldridge, [17]). Bryan et al. [18], also accentuates that the error term for the probit model is implicit to have the standard normal distribution. Furthermore, the probit model has the ability to resolve the problem of heteroscedasticity and also constrain the utility value to lie between 0 and 1. The probit model makes the assumption that while we only observe the values of 0 and 1 for the dependent variable $Y_{i}$, there is a latent, unobserved continuous variable $Y_{i}^{*}$ that determines the value of $Y_{i}$ (Sebopetji \& Belete, [19]).

$$
Y_{i}^{*}=\lambda_{0}+\lambda_{1} \delta_{1 i}+\lambda_{2} \delta_{2 i} \cdots \lambda_{8} \delta_{8 i}+\varepsilon_{i} \cdots e q n
$$

$$
\begin{aligned}
& Y_{i}=1 \text { if } Y^{*}=0 \\
& Y_{i}=0, \text { if otherwise }
\end{aligned}
$$

where $\delta_{i}$ represents a vector of explanatory variables, $\alpha$ is a vector of unknown parameters and $\varepsilon_{i}$ is a random disturbance term (Nagler, [16]; Kuwornu et al. [20]). The probit model is specified for this study as: 


$$
\begin{aligned}
Y_{i}= & \alpha+\beta_{1} G E N_{i}+\beta_{2} A G E_{i}+\beta_{3} E D U_{i}+\beta_{4} B E_{i} \\
& +\beta_{5} T_{i}+\beta_{6} R L_{i}+\beta_{7} S U C_{i}+\beta_{8} A T_{i}+\beta_{9} A M_{i} \\
& +\beta_{10} A C_{i}+\beta_{11} A P S_{i}+\beta_{12} S N_{i}+\mu_{i}
\end{aligned}
$$

The description and mode of measurement of the concerned variables used in the models are presented in Table 1 and Table 2.

\section{Justification of the Explanatory Variables Used in the Logit Model}

Age: This is the age of the retail shop owner and is measured in years. On regard to the age of a respondent, the study might expect the Small and Medium

Table 1. Dependent variable description.

\begin{tabular}{cll}
\hline Variable & \multicolumn{1}{c}{ Description } & \multicolumn{1}{c}{ Mode of Measurement } \\
\hline DNE & $\begin{array}{c}\text { Difference in the number of } \\
\text { employees (Used in OLS) }\end{array}$ & $\begin{array}{l}\text { Difference between the current employment and } \\
\text { the initial employment }\end{array}$ \\
$Y_{i}$ & Dummy (Used in Logistic) & $\begin{array}{l}\text { Dummy: } 1=\text { if the firm is increasing its } \\
\text { employment; } 0=\text { if otherwise }\end{array}$ \\
$Y_{i}$ & Dummy (Used in Probit) & $\begin{array}{l}\text { Dummy: } 1=\text { if the firm is increasing its } \\
\text { employment; } 0=\text { if otherwise }\end{array}$
\end{tabular}

\begin{tabular}{|c|c|c|}
\hline Variable & Description & Mode of Measurement \\
\hline AGE & Age & Years \\
\hline GEN. & Gender & Dummy: $1=$ if the owner is male; $0=$ if otherwise \\
\hline LE & Level of education & Classified into 5 groups \\
\hline BEXP & Business experience & $\begin{array}{l}\text { Dummy: } 1=\text { if the owner has a business experience; } 0= \\
\text { if otherwise }\end{array}$ \\
\hline TRA & Training & $\begin{array}{l}\text { Dummy: } 1=\text { if the owner had entrepreneurship training } \\
\text { on Retail-shops; } 0=\text { if otherwise }\end{array}$ \\
\hline LOC & Location of the enterprise & $\begin{array}{l}\text { Dummy: } 1=\text { if the Firm is near to another firm }(200 \mathrm{~m}) \text {; } \\
0=\text { if otherwise }\end{array}$ \\
\hline SCAP & Start-up capital & Classified into 4 groups \\
\hline TRANS & Access to transportation & $\begin{array}{l}\text { Dummy: } 1=\text { if the owner has an access to transportation; } \\
0=\text { if otherwise }\end{array}$ \\
\hline ACMKT & Access to market & $\begin{array}{l}\text { Dummy: } 1=\text { if the owner has an access to market; } 0=\text { if } \\
\text { otherwise }\end{array}$ \\
\hline ACLOANS & Access to credit facilities & $\begin{array}{l}\text { Dummy: } 1=\text { if the owner has an access to finance; } 0=\text { if } \\
\text { otherwise }\end{array}$ \\
\hline ACPS & Access to power supply & $\begin{array}{l}\text { Dummy: } 1=\text { if the owner has an access to power supply; } \\
0=\text { if otherwise }\end{array}$ \\
\hline SONEK & Social network & $\begin{array}{l}\text { Dummy: } 1=\text { if the owner is involved in social network; } 0 \\
=\text { if otherwise }\end{array}$ \\
\hline
\end{tabular}

Source: Survey data, 2019.

Table 2. Independent variable description.

Source: Survey data, 2019. 
Enterprises owned, and managed by old people would have to perform better than the young ones. This is due to the fact, number of years in doing business give a chance to the business owners, managers and the managers to have enough experience which will increase efficiency, hence better performance (Cooper et al., [21]). We measure age of retail owners in years (interval) as commonly used in literature.

Level of Education: This is measured in various levels of education attained by owners of retail-shops, namely, Basic education, Junior high school, Senior high school, Bachelor's degree, and Master's degree. Education is one of the most widely studied entrepreneurial variables. Presumably education is related to knowledge, skills, problem-solving ability, discipline, motivation, and self-confidence. These may enable the retail shops owners, managers and employees but also entrepreneurs to cope with problems and thereby are more successful. However, it may be that more educated entrepreneurs and Small and Medium Enterprises' owners/managers perceive a higher opportunity cost in staying with a marginal business. This could lead to a higher threshold level of performance in order to stay with a venture (Cooper et al., [21]). Most empirical evidence suggests that enterprises with better-educated owners and managers are more effective and efficient (Zajda, [22]; Onugu, [23]; Alemayehu and Gecho, [15]). As a result, this study expects the education attainment by the SMEs owners and managers to have a positive impact on the growth of microenterprise.

Start-up capital: Start-up capital is a major challenge mostly identified by the owners of existing Small and Medium Enterprises. Shortage of capital has been found by Felsenstein and Schwartz [24] to be the most common constraint confronting all business persons at the start-ups. Most often than not, small business owners borrow from informal financial markets to setup their businesses or typically commence their businesses with finances from their own resources. Low incomes coupled with limited savings of micro-entrepreneurs constrain start-ups, expansion and growth of Small and Medium Enterprises. This is therefore expected that the size of start-up capital of micro-entrepreneurs will impact positively and significantly on the growth of Small and Medium Enterprises in the study area.

Location of enterprise: This is a dummy variable which takes a value of 1 if the enterprise is located 200 meters near to other retail shops, and takes a value of 0 if the enterprise is located afar. According to Sefiani et al. [25], in a rapid changing and hostile environment, owners and managers of Small and Medium Enterprises are required to choose a particular location so as to maximize the performance of Small and Medium Enterprises. The location specific of an enterprise serves as a crucial factor in explaining the performance of the SMEs (Harabi, [26]; Sefiani, et al. [25]; Alemayehu and Gecho, [15]). However, empirical evidence suggests that locating in clusters which derive from potential knowledge leakage and increased competition has adverse repercussions on the growth of Small and Medium Enterprises (Folta et al. [27]; Alcácer, [28]; Alcácer 
\& Chung, [29]). In this study, the location of the enterprise is expected to have a significant positive impact on the growth of Small and Medium Enterprises.

Business Experience. This is a dummy variable which assumes a value of 1 if the Small and Medium Enterprise owner has a business experience and takes a value of 0 if the owner has no business experience. Business experience can improve the growth of Small and Medium Enterprises in two ways; directly by increasing the capabilities of the owners of the Small and Medium Enterprises and employees through the attainment of knowledge and skills; and indirectly increasing owners' social networks. Small and Medium Enterprises owners with more years of business experience are characterized by faster-growing Small and Medium Enterprises. A study by Parker and Ward [30] indicated that entrepreneurs with at least seven years of business experience increased the size of their firms more than those without business experience. Therefore, the study will expect the years of business experience to have a significant positive influence on the growth of Small and Medium Enterprises.

Training: This explanatory variable is a dummy which takes a value of 1 if the owner had entrepreneurship training on Small and Medium Enterprises, and assumes a value of 0 if the owner has never had any form of entrepreneurial training on Small and Medium Enterprises. According to Dessler and Starke [31], training is the hallmark of faster-growing businesses and good managers cannot neglect the influence of effective training on the growth of their businesses. Training equips both the employers and employees with the pre-requisite skills, knowledge, and competencies for a particular job (Symons and Adams, [32]; Appleby, [33]; Dessler and Starke [31]), as such this study will expect training to contribute positively and effectively to the growth of Small and Medium Enterprises in Ghana.

Access to Market. This variable is a dummy which takes a value of 1 if the SMEs owner has an access to market and assumes a value of 0 if the owner has no access to a market. The significance of marketing is very basic to most enterprises. Sales of products are the lifeblood of every business enterprises, and therefore, acquiring them hinges on research and dealing with the current and potential markets correctly. According to Osogo and Nyonje, [34], it may be too minimal to commercially exploit the market for a new commodity, whereas the market for an existing commodity might permanently decline. Per this assertion, business ought to be capable of coping by discovering new markets or replacement of commodities for the current markets, if not, cutback, decline, and finally collapse will be inevitable. The plight of small businesses with respect to market access is again aggravated by the stiff competition from the well-established large firms. The large businesses which are more organized and exhibit many advantages over small businesses are able to penetrate the market and take up even those few opportunities which the small businesses are supposed to exploit (Kimosop, [35]). In support of Hallberg [36], and Blanchflower et al. [37], this study expects that access to market by small businesses will spur the growth rate of Small and Medium Enterprises in Ghana. 
Other Infrastructural Factors: The study incorporated the provision of transportation and electricity (power supply) to capture the impact of other infrastructure on the performance of Small and Medium Enterprises. In this study, access to power supply and transportation are dummy variables which assume a value of 1 if the business owner has access to power supply and transportation, and take a value of 0 if otherwise. The growth of Small and Medium Enterprises is predicted on the accessibility and availability of infrastructure (transportation and electricity) (Kessides, [38]; Ayogu, [39]; Calderón and Servén, [40]). In this study, access to transportation and power supply are expected to have a significant impact on the growth of Small and Medium Enterprises.

Access to Finance: This independent variable is dummied to take a value of 1 if the SMEs owner has an access to finance, and takes a value of 0 if the owner is faced with the lack of access to finance. Small and Medium Enterprises are often discriminated against in their attempt to raise the needed capital for their survival and growth (Deakins et al. [41]). Thus, Small and Medium Enterprises are inequality in connection with their access to credit facilities. Financial institutions are reluctant in lending funds to Small and Medium Enterprises due to their high default rate, and as such prefer lending to well-established large business who have reasonable investments. Meanwhile, banks may not lend to small businesses because of their inadequate collateral and security (Appleby, [33]). A study conducted by Holmes and Zimmer [42] on the access to credit by Small and Medium Enterprises in China suggested that Chinese state banks are interested in lending to large state-owned enterprises, however, as a result of the economic reforms, private Small and Medium Enterprises find their access to credit facilities increasing limited due to new credit restrictions. This will affect the survival and growth of Small and Medium Enterprises as the owners cannot gain access to much needed funds to operate their businesses effectively (Bitler et al. [43]). Premised on previous studies, it is expected that access to credit by Small and Medium Enterprises will enhance the growth of Small and Medium Enterprises in the study area.

Social Network: This is a dummy variable assuming a value of 1 if the owner is involved in social network and also takes a value of 0 if otherwise. The term "social network" is used here to refer to relationships between individuals. Connections across different groups may enhance mobility and be especially useful for Small and Medium Enterprises trying to overcome regulatory or other obstacles Having an extensive social network is a valuable asset, which can help an entrepreneur obtain access to information. While social networks can enhance Small and Medium Enterprises growth in any context, they can be critical to firms' growth prospects in environments with pervasive market failures (Fafchamps, [44]). All other factors being constant, entrepreneurs and Small and Medium Enterprises' owners/managers with strong social network have higher probability of enhancing the growth of their businesses than those Small and Medium Enterprises who have no social network (Gezahegn et al. [45]). This is 
because social network helps entrepreneurs to overcome the obstacles related of transaction cost, contract enforcement, and regulations. In this study, social network is expected to have a significant positive influence on probability of microenterprise's growth.

The study finds it imperative in using numerous empirical models in other to know the behavior of the variables in question because to make a strong case the researcher has to conduct a robust checking in other to come in to a firm conclusion on the variable as compared to the other studies that dwell on only one model.

\section{Empirical Results and Analysis}

\subsection{Demographic Characteristics of Respondents}

The study performed a cross tabulation in order to examine the relative contribution of each variable on the growth of retail shops in Ghana. The results are displayed in Table 3. Out of the 348 total sample collected from the field, non-growing group comprise of 132 respondents whereas 216 of the respondents belong to the growing group of retail shops. The statistic reveals that there are quite a number of growing retail shops in the country. Similarly, 132 respondents fall under the non-grouping group of retail shops with respect to various age ranges outlined in the questionnaire and 216 respondents on the other hand fall within the growing group having its majority ranging within the ages of 25 to 34 years. The growing Retail shops can be noted for the energetic youth that its employees couple with cheap labor.

Empirical studies portrayed that formal education has a positive influence on the growth of Retail-shops. The table below reveals that a total of 132 respondents fall under non-growing Retail shops out of which only 58 of these respondents admitted to have some level of experience in relation to retailing. Meanwhile, a whopping number of 74 also expressed their inability to be well informed on retailing. In the case of respondents that fall under the growing group, 150 respondents out of the total 216 admitted to the fact that they have some level of experience. A difference of 92 respondents from the growing retail shops alone constitute $53.36 \%$ indicating more than half of the total respondents that are experienced in the non-growing group of retail shops. Out of the growing Retail shops 81 of Retail shops owners are completed basic education, 93 completed junior high school, 39 completed senior high school and 3 had their first degree.

Researches have proven the importance of finance to the growth a business. From Table 3, it is evidential that majority of the non-growing retail shops do not have enough start-up capital (some between 20,000 and 30,000 and even below). The result revealed that there are some growing retail shops in this category, however, there are other factors constituting to their growth apart from start-up capital. In relation to access to good roads, 91 retail shops owners express that they do not have access to good roads and this has influenced the 
Table 3. Cross tabulation of retail shop.

\begin{tabular}{|c|c|c|c|c|}
\hline \multirow{2}{*}{ Variable } & \multirow{2}{*}{ Category } & \multirow{2}{*}{$\frac{\text { Non-Growing }}{\mathrm{N}}$} & \multirow{2}{*}{$\begin{array}{c}\text { Growing } \\
\mathrm{N}\end{array}$} & \multirow{2}{*}{$\begin{array}{c}\text { Total } \\
\mathbf{N}\end{array}$} \\
\hline & & & & \\
\hline \multirow[t]{4}{*}{ Gender } & Male & 60 & 96 & 156 \\
\hline & Female & 72 & 120 & 192 \\
\hline & Below 18 & 9 & 45 & 54 \\
\hline & $18-24$ & 8 & 50 & 58 \\
\hline \multirow[t]{3}{*}{ Age } & $25-34$ & 3 & 76 & 79 \\
\hline & $35-44$ & 96 & 42 & 138 \\
\hline & 45 above & 16 & 3 & 19 \\
\hline \multirow[t]{2}{*}{ Experience } & No experience & 74 & 66 & 140 \\
\hline & Has experience & 58 & 150 & 208 \\
\hline \multirow[t]{4}{*}{ Education } & Basic Education & 0 & 81 & 81 \\
\hline & Junior High School & 19 & 93 & 112 \\
\hline & Senior High School & 90 & 39 & 129 \\
\hline & Bachelor & 23 & 3 & 26 \\
\hline \multirow[t]{2}{*}{ Training } & No Training & 90 & 88 & 178 \\
\hline & Has Training & 42 & 128 & 170 \\
\hline \multirow[t]{3}{*}{ Location } & Not Close to other business & 82 & 81 & 163 \\
\hline & Close to other business & 50 & 135 & 185 \\
\hline & $<20,000$ & 30 & 118 & 148 \\
\hline \multirow[t]{2}{*}{ Start-up Capital } & $20,000-30,000$ & 65 & 86 & 151 \\
\hline & $30,000-40,000$ & 12 & 49 & 49 \\
\hline \multirow[t]{2}{*}{ Access to Road } & No access & 91 & 96 & 187 \\
\hline & Has access & 41 & 120 & 161 \\
\hline \multirow[t]{2}{*}{ Power Supply } & No power supply & 78 & 92 & 170 \\
\hline & Has power supply & 54 & 124 & 178 \\
\hline \multirow[t]{3}{*}{ Social Network } & No Social network & 71 & 101 & 172 \\
\hline & Has Social network & 61 & 115 & 176 \\
\hline & Total & 132 & 216 & 348 \\
\hline
\end{tabular}

Source: Field Survey, 2019. Authors' computation.

growth of their business. This is because their counterpart growing retail shops that have almost 100 retail shops owners who admitted that they have access to good roads also agreed that in operating their businesses, they find it easier to transport to and from any time.

Over the past years, electricity tariffs have kept on rising. Statistics from the gazette published by PURC have shown 78.9\% increase in electricity tariffs for 2012 and 2013. In the year 2013 to 2014, an increment of 31\% was seen again 
and from 2014 to 2015, another increment of 63\% was realised. These increment in the electricity tariffs means that, the consumers of electricity (Retail shops in the case of this research) would have to pay more for electricity, in the course of running their businesses. Energy supply is the major driving force for business sustainability in today's competitive world. Over the past years, electricity tariffs have kept on rising. Statistics from the gazette published by PURC have shown 78.9\% increase in electricity tariffs for 2012 and 2013. In the year 2013 to 2014, an increment of $31 \%$ was seen again and from 2014 to 2015, another increment of $63 \%$ was realised. This increment in the electricity tariffs means that, the consumers of electricity (Retail shops in the case of this research) would have to pay more for electricity, in the course of running their businesses. Energy supply is the major driving force for business sustainability in today's competitive world. In Table 3, it seen that about 78 retail shops owners are not having access to electricity. In the case of growing retail shops only 92 against 124 retail shops owners are not supplied with electricity.

\subsection{Regression Results and Its Interpretation of the Study}

In order to analyze the determinants of retail shop growth in Ghana, the study performed several regression analyses. The estimation of the Ordinary Least Square study revealed that gender does not influence the growth of retail growth. The results presented in Table 4 display the effects of the effect of the independent variables on the dependent variable. From the results of the multiple linear regression displayed in Table 4 , the $\mathrm{R}^{2}$ is 0.42 , indicating that $42 \%$ of the variations in the dependent variable (employment) is explained jointly by the independent variables (age; education; access to credit; and access to market etc). Age on other hand negatively related to the growth of retail growth. According to the life cycle theory, the financial behavior differs for the youth and the elderly, as compared to the mature. The increase in the average life span imposes the increase of the saving rate during the active life with the view to maintaining the level of consumption (living standard) during the active life. The level of Education of the respondents indicated a negative and significant effect on the of retail shops growth through the estimation of OLS. Education is key irrespective of any business one finds himself. The level of education, Experience, Training and access to credit facility was not significant. Startup capital, power supply and social network all negatively influence the growth of retail shops. Access to transportation and access to market had positively influence the growth of retail shops (Table 4, Table 5).

The study further used a logistic regression to estimate the impacts of the variables on the growth of retail shops. The results indicated that gender, experience and access to credit are statistically insignificant through the estimation of the logistic regression model. The result of the experience variable however, agrees with the findings of Alemayehu and Gecho [15] whom in their logistic regression output found experience of business owners in Ethiopia to have a 
Table 4. OLS, logit and probit model results on determinants of retail-shops.

\begin{tabular}{|c|c|c|c|}
\hline & (1) & (2) & (3) \\
\hline VARIABLES & OLS & Logit & Probit \\
\hline \multirow[t]{2}{*}{ Gender } & 0.1217 & -0.0441 & -0.1254 \\
\hline & $(0.177)$ & $(0.483)$ & $(0.266)$ \\
\hline \multirow[t]{2}{*}{ Age } & $-0.5584^{* * *}$ & $-0.9879^{\star * *}$ & $-0.4794^{* * *}$ \\
\hline & $(0.103)$ & $(0.246)$ & $(0.132)$ \\
\hline \multirow[t]{2}{*}{ Education } & $-0.448^{\star *}$ & $-2.7488^{\star * *}$ & $-1.3698^{\star * *}$ \\
\hline & $(0.146)$ & $(0.508)$ & $(0.245)$ \\
\hline \multirow[t]{2}{*}{ Experience } & -0.1019 & 0.2653 & 0.0404 \\
\hline & $(0.257)$ & $(0.602)$ & $(0.328)$ \\
\hline \multirow[t]{2}{*}{ Training } & 0.098 & $1.5129^{* * *}$ & $0.7060^{* * *}$ \\
\hline & $(0.171)$ & $(0.466)$ & $(0.243)$ \\
\hline \multirow[t]{2}{*}{ Location } & 0.2212 & $0.8609^{*}$ & 0.4160 \\
\hline & $(0.234)$ & $(0.518)$ & $(0.291)$ \\
\hline \multirow[t]{2}{*}{ Startup capital } & $-0.5043^{* *}$ & $-0.9909^{* *}$ & $-0.5842^{* * *}$ \\
\hline & $(0.145)$ & $(0.397)$ & $(0.211)$ \\
\hline \multirow[t]{2}{*}{ Access to transportation } & $0.771^{* * *}$ & $1.7317^{* * *}$ & $0.8635^{* * *}$ \\
\hline & $(0.177)$ & $(0.463)$ & $(0.241)$ \\
\hline \multirow[t]{2}{*}{ Access to market } & $1.0247^{\star * *}$ & $2.1978^{\star * *}$ & $1.2425^{\star * *}$ \\
\hline & $(0.201)$ & $(0.555)$ & $(0.296)$ \\
\hline \multirow[t]{2}{*}{ Access to credit facility } & 0.2082 & -0.2113 & -0.0675 \\
\hline & $(0.193)$ & $(0.427)$ & $(0.240)$ \\
\hline \multirow[t]{2}{*}{ Power supply } & 0.3022 & $0.9108^{\star \star}$ & $0.4039^{*}$ \\
\hline & $(0.172)$ & $(0.425)$ & $(0.232)$ \\
\hline \multirow[t]{2}{*}{ Social network } & $-0.841^{\star * *}$ & $-2.8790^{\star * *}$ & $-1.5043^{* * *}$ \\
\hline & $(0.202)$ & $(0.540)$ & $(0.283)$ \\
\hline \multirow[t]{2}{*}{ Constant } & $3.3592^{\star * *}$ & $10.3227^{\star * *}$ & $5.4162^{\star \star \star}$ \\
\hline & $(0.411)$ & (1.589) & $(0.788)$ \\
\hline Observations & 348 & 348 & 348 \\
\hline $\mathrm{R}^{2}$ & 0.416 & 0.5889 & 0.5745 \\
\hline
\end{tabular}

Source: Researcher's Field Data, 2019. Note: ${ }^{*} \mathrm{p}<0.05 ;{ }^{* *} \mathrm{p}<0.01$ indicate significant at $5 \%$ and $1 \%$. Standard errors are listed in parentheses.

Table 5. Ordered logit and probit results on determinants of retail-shops.

\begin{tabular}{ccc}
\hline & $(1)$ & $(2)$ \\
\hline VARIABLES & Ordered logit & Ordered Probit \\
Gender & -0.1201 & -0.0976 \\
Age & $(0.368)$ & $(0.220)$ \\
\end{tabular}




\begin{tabular}{|c|c|c|}
\hline Continued & & \\
\hline & $(0.179)$ & $(0.105)$ \\
\hline Education & $-1.7649^{\star * *}$ & $-0.9930^{\star * *}$ \\
\hline & $(0.338)$ & $(0.187)$ \\
\hline Experience & 0.2772 & 0.1423 \\
\hline & $(0.442)$ & $(0.262)$ \\
\hline Training & $1.2158^{\star * *}$ & $0.6146^{\star * *}$ \\
\hline & $(0.346)$ & $(0.194)$ \\
\hline Location & 0.4455 & 0.2484 \\
\hline & $(0.407)$ & $(0.243)$ \\
\hline Start-up capital & $-0.7722^{\star \star \star}$ & $-0.4636^{\star * *}$ \\
\hline & $(0.289)$ & $(0.164)$ \\
\hline Access to road & $0.8687^{\star * *}$ & $0.5610^{\star * *}$ \\
\hline & $(0.328)$ & $(0.188)$ \\
\hline Access to market & $1.5924^{* * *}$ & $0.9583^{* * *}$ \\
\hline & $(0.392)$ & $(0.226)$ \\
\hline Access to credit facility & 0.0698 & 0.0526 \\
\hline & $(0.337)$ & $(0.199)$ \\
\hline Power supply & 0.4349 & 0.2350 \\
\hline & $(0.309)$ & $(0.181)$ \\
\hline Social network & $-1.8832^{\star * *}$ & $-1.0391^{\star \star \star}$ \\
\hline & $(0.385)$ & $(0.216)$ \\
\hline Pseudo- $\mathrm{R}^{2}$ & 0.3793 & 0.3808 \\
\hline Observations & 348 & 348 \\
\hline
\end{tabular}

Source: Researcher's Field Data, 2019 Note: ${ }^{* *} \mathrm{p}<0.05 ;{ }^{* *} \mathrm{p}<0.01$ indicate significant at $5 \%$ and $1 \%$. Standard errors are listed in parentheses.

positive impact but insignificant and the expected priori sign proposed by the researcher but contradicts the findings of Parker and Ward [30]. The study again ascertained that, Age, Education, Startup capital, Power supply and social network negatively influence the growth of retail shops. Capital is very imperative for every business operation. Capital accumulation for start-up businesses has been a major issue in literature. The problems of start-up capital are severed in most developing countries such as Ghana. In this regard the study considers the variable start-up capital as a key variable of interest in the study. It is not surprising as the study has shown a negative significant impact on the growth of retail shops in Ghana. Ghana has a high rate of interest rate which serve as a major obstacle to start-up business in the country and also contribute to the collapse of existing ones that cannot afford to pay. As on 27th May, 2019 the bank of Ghana prime lending rate stood at $16 \%$. Due to the high interest rate charged by the banks, start-up businesses coupled with existing ones finds it difficult to excel 
which affect their growth. Most businesses in Ghana are retail businesses hence the high interest rate affects the general price of goods which at long run affect the growth of the business. The findings of the current study have revealed the reality in the Ghanaian economy with an evidence of the negative impact it has on the growth of retail shops in Ghana. The finding is in line with Alemayehu and Gecho [15] whom in their study revealed that start-up has negative influence but significant on the growth of SMEs in Ethiopia.

In a swiftly moving and hostile environment, owner-managers of SMEs engage with others in building a robust relation and to interact strongly and efficiently with internal and external members to maximize business growth but this is not the case in Ghana. This result violates the law of the resource dependency theory (Barringer \& Harrison, [46]), which states that entrepreneurs utilized their social relations to get the resources they need to support their business (Hansen, [47]) and also contradict the theory of networking which suggests that there is a positive connection between social networking and some parts of business growth. The result of the study contradicts the study of Chen, Chan and Chung, [48] who revealed that social network has a positive relationship to the growth of firms because they are of the view that there are numerous benefits that can be obtained through social networking such as information about business opportunity, innovation and others. The Ghanaian businesses lack this opportunity due to the high interference of family and high dependence rate of family on young entrepreneurs in the country.

Isaksson and Storbjörk, [49] found that, the existence of reliable electricity infrastructure plays a significant role in firms' growth and development disparities which happens to be in agreement with this finding. Electricity provides business owners with access to online information and resources. The study further disclosed that, Access to transportation, and Access to market, positively influence the growth of retail shops. The findings of the variable access to market agree the studies of Hallberg [36], and Blanchflower et al. [37].

The study further used a probit regression to estimate the impacts of the variables on the growth of retail shops. The results suggested that gender, experience and access to credit are statistically insignificant from the estimation of the probit regression model. The study again portrayed that, Age, Education, Startup capital, Power supply and social network negatively related to the growth of retail shops. The study further disclosed that, Access to transportation, and Access to market, positively influence the growth of retail shops. The findings of the variable Access to market is line with the studies of Hallberg [36], and Blanchflower et al. [37].

Lastly, the study considered the consistency of the factors on all the three models used in estimating the determinants and it was revealed that some of the factors were consistent across all the models used whiles others were not. The study portrayed that age, education, start-up capital and social network were consistently negative in all the three models (OLS, Logit and Probit model) 
whiles gender and access to credit facility were negatively consistent in only logit and the probit model. On the other side of the coin it was seen that training, location, access to transportation, access to market and power supply were consistently positive in all the three model whiles experience was consistently positive in logit and probit model but the rest were not.

\subsection{Ordered Logit and Probit Regression Results on Determinants of Retail Shops}

In order to further examine the determinants of retail shops growth in Ghana, this study also performed ordered logit and ordered probit regressions. However, the ordinary least square, the binary logistic and binary probit regression answers the question as to whether retail shops are growing or not growing whereas in their ordered estimations, they seek to deeply investigate the various influences they have on the retail shops when they are growing and not growing. From the study it was shown that experience, training, location and access to road, access to market, access to credit facility and power supply are positively related to growth. For instance, shops owned by experienced retail owners are more likely to improve performance of their retail shops. Similarly, shops owned by trained personnel are more likely to increase the performance of their business. On the other hand, the study portrayed that gender, age, education, start-up capital and social network are negatively related to the growth of retail shops in Ghana. For example, an additional increase in age by one year is less likely to increase the growth of retail shops. As popular said "Age comes with responsibility" and age in itself is an avoidable, hence the more a retail-shop owner grows the more responsibilities abound and the lesser investment will the owner be willing to invest.

\section{Conclusions and Policy Recommendations}

With respect to the analysis, age was statistically significant at $5 \%$ and negative. This implies that age has negative effect on the growth of retail shops. Following the theory of life cycle, the age of retail shops owners has a negative impact on the growth of their business in the sense that, they are willing to invest more into the business at their youthful age and rather avoid investing more when they are matured or attain the retirement age. The result of the study contradicts the finding of Rose et al. (2006) who suggested that age of a person is positively related to the growth of his business. Investment in the business at their active age will have a positive impact on the growth of the business. The importance of education in the life of every individual is undebatable. Lack of education will influence the growth of retail shops negatively; therefore there is the need for owners of retail shops that not only relies on school systems but also should endeavor to adapt to the changes in the $21^{\text {st }}$ area which can translate into a positive influence on the growth because it will help breed to skill acquisition and managerial competencies. 
Source of finance to start a business has been a generational problem for decades. This is very severe in developing countries especially in Africa of which Ghana is no exception too. Inadequate capital has been found in literature to be the most common constraint confronting all business owners at the start-ups. Start-up capital is an engine of most business because it serves as a catalyst that has influence on the growth of the business which must not be underestimated. This study discovered that start-up capital of retail shops owners has a negative and significant impact on the growth of retail-shops. This finding clearly establishes the lack of domestic support to local firms in Africa and has affirmed the whopping assertions regarding the low level of access to credit in Ghana and Africa as a whole. The study hence contributes to arising issues of the essential need of start-up capitals for retail shops around the world. Interestingly, location was expected to be positive based on the consideration of the monopolistic theory of retail shops that find the SMEs with no competition turns out to be positive and significant. The study therefore affirms the monopolistic theory. It was found that access to power is significant and has a positive influence effect on retail shops' growth. According to Isaksson and Storbjörk [49], it was showed that, the existence of sustainable electricity power supply plays an important role in firms' growth and development. Good infrastructure is a key developmental indicator in any country. Infrastructure serves as the avenue for different activities. For instance, good roads aid the ease in the transportation of foodstuffs from the rural areas to the market places. In this study, it was affirmed that access to transportation is statistically significant and has a positive impact on retail shops' growth. The revelation of the study admits to the works of Kiprotich et al., [50], Hallberg [36], and Blanchflower et al. [37], that access to good road has a positive influence of the growth of Retail-shops.

Regards to the findings of this study, it was revealed that access to market is significant but has positive effect on the growth of retail shops which confirms the revelations of Kiprotich et al., [50]; Hallberg [36], and Blanchflower et al. [37]). The macroeconomic factors that contribute to the purchasing of goods and service have to be flexible to enable good standard of living that citizens can afford commodities. The study further showed that training to Retail shops has a positively significant impact on retail shops growth. The results happen to disagree with Garoma [51] and Gezahegn et al. [52] who discovered in their study that there is no significant relationship between training of business owner and growth of retail shops but it agrees with the study conducted by Alemayehu and Gecho [15]; and Dessler and Starke [53] who established that training prepares both employers and employees. The study based on the logistic regression model, indicated that access to credit has a negative and insignificant influence on the retail shops growth. The result contradicts scholars such as: Nuwagaba, and Nzewi [52], Beck et al. [53] and Ayyagari et al. [54]. The finding of this study portrayed that business experience of retail shops owners has a positive impact and also not significant at any conventional level of significance. 
There is growing preference by affluent and upper middle classes for shopping at modern organized retail-shops, given the convenience they offer such as shopping ambience, variety and a single point source of purchases. There is no doubt that traditional retail has been performing a vital function in the economy and significant source of employment. Bearing this assertion in mind the researcher focused on investigating the determinants of retail shops growth in Ghana. The main objective of the study is to examine the factors that influence the growth of retail shops within the Accra Metropolis in the greater Accra Region of Ghana. After several ethical consideration of research, the study collected data from 348 retail shops and through the adaptation of logistic regression model the study came into conclusion that factors such as; training, access to market and access to transportation are the only factors that influence the growth of retail-shops positively whereas gender, age, education, start-up capital, and social network influence growth negatively. The factors are significant at various level of conventional significance as indicated in the logistic regression table above. The study also concludes that business experience of retail shops owners and access to credit have a positive and negative impact on the growth of retail shops and are not significant at any conventional level of significance respectively. It is accepted that in a future a rigorous research design will be included in the work. The study found out that, loss of revenue due to high purchasing of power, increasing cost of production due to unstable power supply, increased cost of extending services through other alternative channels, increased competition in the industry, and Poor record keeping habit among the retail-shop owners are all challenges that retail-shop owners encounter in daily operations in Ghana. With respect to this finding, government needs to urgently direct major attention towards the energy sector of the economy.

The study further deduced that training, access to market and access to transportation are the factors that influence the growth of retail-shops positively hence accessibility to market through good roads should be enhanced all over in the country in order to encourage growth of other sectors as well. The study again discovered that start-up capital, and social network influence growth negatively. This could be a result of negative usage of these two factors. Thus, to say that start-up capitals are not directly used for the business as expected and social network is equally used for other things apart from the business. Hence, retail-shop owners need to pay critical attention to the usage of their start-up capital and should also open up to others in order to be socially connected.

\section{Conflicts of Interest}

The authors declare no conflicts of interest regarding the publication of this paper.

\section{References}

[1] Ahiawodzi, A.K. and Adade, T.C. (2012) Access to Credit and Growth of Small and Medium Scale Enterprises in the Ho Municipality of Ghana. British Journal of 
Economics, Finance and Management Sciences, 6, 34-51.

[2] Berman, B. and Evans, J.R. (2005) Retail Management: A Strategic Approach. 8th Edition, Pearson Education, Singapore.

[3] Kim, C., Galliers, R.D., Shin, N., Ryoo, J.H. and Kim, J. (2012) Factors Influencing Internet Shopping Value and Customer Repurchase Intention. Electronic Commerce Research and Applications, 11, 374-387. https://doi.org/10.1016/j.elerap.2012.04.002

[4] Londhe, B.R. (2006) Retail and Distribution Management. Nirali Prakashan, Mumbai.

[5] Liu, Z., Zhao, R., Liu, X. and Chen, L. (2017) Contract Designing for a Supply Chain with Uncertain Information Based on Confidence Level. Applied Soft Computing, 56, 617-631. https://doi.org/10.1016/j.asoc.2016.05.054

[6] Chen, L., Peng, J., Liu, Z. and Zhao, R. (2017) Pricing and Effort Decisions for a Supply Chain with Uncertain Information. International Journal of Production Research, 55, 264-284. https://doi.org/10.1080/00207543.2016.1204475

[7] Baum, J., Locke, E. and Smith, K. (2001) A Multidimensional Model of Venture Growth. Academy of Management Journal, 44, 292-303. https://doi.org/10.5465/3069456

[8] Masurel, E. and Van Montfort, K. (2006) Life Cycle Characteristics of Small Professional Service Firms. Journal of Small Business Management, 44, 461-473. https://doi.org/10.1111/j.1540-627X.2006.00182.x

[9] Autio, E. (2005) Creative Tension: The Significance of Ben Oviatt's and Patricia McDougall's Article toward a Theory of International New Ventures. Journal of International Business Studies, 36, 9-19. https://doi.org/10.1057/palgrave.jibs.8400117

[10] Herath, H.A. and Mahmood, R. (2013) Strategic Orientation Based Research Model of SME Performance for Developing Countries. Review of Integrative Business and Economics Research, 2, 430.

[11] Stuart, R.W. and Abetti, P.A. (1990) Impact of Entrepreneurial and Management Experience on Early Performance. Journal of Business Venturing, 5, 151-162. https://doi.org/10.1016/0883-9026(90)90029-S

[12] Begley, T.M. and Boyd, D.P. (1987) A Comparison of Entrepreneurs and Managers of Small Business Firms. Journal of Management, 13, 99-108. https://doi.org/10.1177/014920638701300108

[13] Chandler, G.N. and Jansen, E. (1992) The Founder's Self-Assessed Competence and Venture Performance. Journal of Business Venturing, 7, 223-236. https://doi.org/10.1016/0883-9026(92)90028-P

[14] Davidsson, P. and Wiklund, J. (2006) Conceptual and Empirical Challenges in the Study of Firm Growth. Entrepreneurship and the Growth of Firms, 1, 39-61. https://doi.org/10.4337/9781781009949.00010

[15] Alemayehu, D. and Gecho, Y. (2016) Determinants of Micro and Small Enterprises Growth: The Case of Durame Town, Kembata Tembaro Zone, Southern Nations and Nationalities and Peoples Region, Ethiopia, 2016. International Journal of Business and Economics Research, 5, 161. https://doi.org/10.11648/j.ijber.20160505.15

[16] Nagler, J. (2002) Interpreting Probit Analysis. New York University, New York.

[17] Wooldridge, J.M. (2006) Introductory Econometrics: A Modern Approach. 3rd Edition, Thomson, New York.

[18] Bryan, P.L., Abel, M.R., Davenport Jr., F.B., Davis, W.R., Fisher, R.A., Furr, D.M., 
Lilien, R.S., et al. (2009) About the 2009.

[19] Sebopetji, T.O. and Belete, A. (2009) An Application of Probit Analysis to Factors Affecting Small-Scale Farmers Decision to Take Credit: A Case Study of the Greater Letaba Local Municipality in South Africa. African Journal of Agricultural Research, 4, 718-723.

[20] Kuwornu, J.K., Mensah-Bonsu, A. and Ibrahim, H. (2011) Analysis of Foodstuff Price Volatility in Ghana: Implications for Food Security. European Journal of Business and Management, 3, 100-118.

[21] Cooper, A.G. and Woo, C. (1991) Initial Human and Financial Capital as Predictors of New Venture Performance. Krannert Graduate School of Management, Purdue University, West Lafayette, 40-64.

[22] Zajda, J. (2004) King, Kenneth, and Simon McGrath. 2002. Globalisation, Enterprise and Knowledge: Educational Training and Development. International Review of Education, 50, 74-76. https://doi.org/10.1023/B:REVI.0000018307.23287.74

[23] Onugu, C.U. (2008) Advancing Women Participation in Agricultural Development through Cooperative Societies: The Case of Women in Agriculture Programme in Anambra State, Nigeria. Nigerian, Journal of Cooperative Economics and Management, 4, 66-77.

[24] Felsenstein, D. and Schwartz, D. (1993) Constraints to Small Business Development across the Life Cycle: Some Evidence from Peripheral Areas in Israel. Entrepreneurship \& Regional Development, 5, 227-246. https://doi.org/10.1080/08985629300000014

[25] Sefiani, Y., Davies, B. and Bown, R. (2016) The Perceptual Effects of Location on the Performance of Small Businesses. MPRA Paper No. 74768. https://mpra.ub.uni-muenchen.de/74768

[26] Harabi, N. (2003) Determinants of Growth: An Empirical Analysis from Morocco. Solothurn University of Applied Sciences, Solothurn.

[27] Folta, T.B., Cooper, A.C. and Baik, Y. (2006) Geographic Cluster Size and Firm Performance. Journal of Business Venturing, 21, 217-242. https://doi.org/10.1016/j.jbusvent.2005.04.005

[28] Alcácer, J. (2006) Location Choices across the Value Chain: How Activity and Capability Influence Collocation. Management Science, 52, 1457-1471. https://doi.org/10.1287/mnsc. 1060.0658

[29] Alcácer, J. and Chung, W. (2007) Location Strategies and Knowledge Spillovers. Management Science, 53, 760-776. https://doi.org/10.1287/mnsc.1060.0637

[30] Parker, C. and Ward, P. (2000) An Analysis of Role Adoptions and Scripts during Customer-to-Customer Encounters. European Journal of Marketing, 34, 341-359. https://doi.org/10.1108/03090560010311894

[31] Dessler, G. and Starke, F.A. (2004) Management: Principles and Practices for Tomorrow's Leaders. Pearson/Prentice Hall, U Upper Saddle River.

[32] Symonds, D. and Andrew, A. (1992): Business Studies. M and A Thompson, Glasgow.

[33] Appleby, S. (1994) Mobile Software Agents for Control in Telecommunications Networks. BT Technology Journal, 12, 104-113.

[34] Osogo, J.A. and Nyonje, R.O. (2015) Influence of Administrative Structures in Local Authority Service Delivery Action Program Implementation, on the Level of Satisfaction in Provision of Community Services in Kisumu City, Kenya.

[35] Kiprotich, S., Kimosop, J., Kemboi, A. and Chepkwony, P.K. (2015) Moderating Ef- 
fect of Social Networking on the Relationship between Entreprenual Orientation and Performance of Small and Medium Enterprise in Nakuru County, Kenya.

[36] Hallberg, K. (2000) A Market-Oriented Strategy for Small and Medium Scale Enterprises. The World Bank, Washington DC. https://doi.org/10.1596/0-8213-4727-6

[37] Blanchflower, D.G., Levine, P.B. and Zimmerman, D.J. (2003) Discrimination in the Small-Business Credit Market. Review of Economics and Statistics, 85, 930-943. https://doi.org/10.1162/003465303772815835

[38] Kessides, C. (1993) The Contributions of Infrastructure to Economic Development: A Review of Experience and Policy Implications. The World Bank, Washington DC. https://doi.org/10.1596/0-8213-2628-7

[39] Ayogu, M. (2007) Infrastructure and Economic Development in Africa: A Review. Journal of African Economies, 16, 75-126. https://doi.org/10.1093/jae/ejm024

[40] Calderón, C. and Servén, L. (2004) The Effects of Infrastructure Development on Growth and Income Distribution. The World Bank, Washington DC.

https://doi.org/10.1596/1813-9450-3400

[41] Deakins, D., Freel, M.S. and Mason, K. (1999) Entrepreneurship and Small Firms.

[42] Holmes and Zimmer (1994) The Nature of Small Firm. Australian Journal of Management, 19, 97-120. https://doi.org/10.1177/031289629401900106

[43] Bitler, M.P., Robb, A.M. and Wolken, J.D. (2001) Financial Services Used by Small Businesses: Evidence from the 1998 Survey of Small Business Finances. Federal Reserve Bulletin, 87, 183.

[44] Fafchamps, M. (2000) Ethnicity and Credit in African Manufacturing. Journal of Development Economics, 61, 205-235.

https://doi.org/10.1016/S0304-3878(99)00068-1

[45] Gezahegn, A., Zewdie, S. and Amentie, C. (2015) Factors Determining the Success of Micro and Small Enterprises in Ethiopia (The Case of Arbaminch Town). Social and Business Science Review, 3, 69-76.

[46] Barringer, B.R. and Harrison, J.S. (2000) Walking a Tightrope: Creating Value through Interorganizational Relationships. Journal of Management, 26, 367-403. https://doi.org/10.1177/014920630002600302

[47] Hansen, T. (2008) Consumer Values, the Theory of Planned Behaviour and Online Grocery Shopping. International Journal of Consumer Studies, 32, 128-137. https://doi.org/10.1111/j.1470-6431.2007.00655.x

[48] Chen, Y.T., Chan, F.T.S. and Chung, S.H. (2015) An Integrated Closed-Loop Supply Chain Model with Location Allocation Problem and Product Recycling Decisions. International Journal of Production Research, 53, 3120-3140. https://doi.org/10.1080/00207543.2014.975849

[49] Isaksson, K. and Storbjörk, S. (2012) Strategy Making and Power in Environmental Assessments. Lessons from the Establishment of an Out-of-Town Shopping Centre in Västerås, Sweden. Environmental Impact Assessment Review, 34, 65-73. https://doi.org/10.1016/j.eiar.2012.01.001

[50] Rose, R.C., Kumar, N. and Yen, L.L. (2006) The Dynamics of Entrepreneurs' Success Factors in Influencing Venture Growth. Journal of Asia Entrepreneurship and Sustainability, 2, 133. https://doi.org/10.3844/jssp.2006.74.80

[51] Garoma, B.F. (2012) Determinants of Microenterprise Success in the Urban Informal Sector of Addis Ababa: A Multidimensional Analysis.

[52] Nuwagaba, A. and Nzewi, H. (2013) Major Environmental Constraints on Growth of Micro and Small Enterprises in Uganda: A Survey of Selected Micro and Small 
Enterprises in Mbarara Municipality. International Journal of Cooperative Studies, 2, 26-33. https://doi.org/10.11634/216826311302298

[53] Beck, T. and Demirguc-Kunt, A. (2006) Small and Medium-Size Enterprises: Access to Finance as a Growth Constraint. Journal of Banking \& Finance, 30, 2931-2943. https://doi.org/10.1016/j.jbankfin.2006.05.009

[54] Ayyagari, M., Demirguc-Kunt, A. and Maksimovic, V. (2014) Who Creates Jobs in Developing Countries? Small Business Economics, 43, 75-99.

https://doi.org/10.1007/s11187-014-9549-5 